\title{
Analisis Spasio-Temporal Perubahan Luas Lahan Garam di Pesisir Kabupaten Rembang
}

\author{
Spatio-Temporal Analysis of Salt Ponds Change in Rembang Coastal Area
}

\author{
Edwin Maulana ${ }^{1}$ \\ Badan Informasi Geospasial, Bogor, Indonesia

\section{Guridno Bintar Saputro} \\ Badan Informasi Geospasial, Bogor, Indonesia \\ Suprajaka Suprajaka \\ Badan Informasi Geospasial, Bogor, Indonesia
}

\section{Cahyawati Mandala Sari}

Badan Pusat Statistik, Jakarta, Indonesia

Artikel Masuk : 4 Februari 2020

Artikel Diterima : 25 November 2020

Tersedia Online : 31 Desember 2020

\begin{abstract}
Abstrak: Konsumsi garam yang terus meningkat tidak sebanding dengan pertambahan lahan produksi garam. Pemetaan tambak garam selama ini dilakukan pada skala kecil hingga menengah, sehingga akurasinya tidak terlalu baik. Penelitian ini bertujuan untuk menganalisis perubahan luas lahan garam pada skala besar yang ada di Kabupaten Rembang selama periode 2005-2015. Sumber data yang digunakan adalah Citra Satelit Resolusi Sangat Tinggi (CSRST) yang sudah terortorektifikasi serta data sekunder. Luas lahan garam dihitung melalui interpretasi visual dan deteksi manual. Penggunaan data CSRST dengan metode interpretasi visual dan deteksi manual memiliki keunggulan dalam hal akurasi geometrik dibandingkan dengan penggunaan citra berskala menengah dengan metode otomatisasi. Hasil analisis menunjukkan bahwa luas lahan garam di Kabupaten Rembang bertambah selama periode 2005-2015. Pertambahan paling besar terjadi pada periode 2005-2011, yaitu bertambah sebesar 546,255 ha atau sebesar 32\%. Penambahan luas pada periode 2011-2015 tidak terlalu signifikan, yaitu sebesar 198,45 ha $(11,46 \%)$. Pertambahan luas lahan garam diperkirakan masih akan terjadi dalam beberapa tahun mendatang, namun nilainya tidak akan signifikan karena pemanfaatan lahan di sebagian besar pesisir Kabupaten Rembang sudah optimal. Perluasan tambak garam memungkinkan dilakukan dengan cara mengonversi sawah yang ada di pesisir Kabupaten Rembang. Kajian perbandingan terhadap nilai ekonomi sawah dan tambak garam harus dilakukan sebelum dilakukan konversi lahan sawah menjadi tambak garam.
\end{abstract}

Kata Kunci: luas lahan garam; pendekatan spasial; perubahan penggunaan lahan; tambak garam,

\footnotetext{
${ }^{1}$ Korespondensi Penulis: Badan Informasi Geospasial, Bogor, Indonesia Email: edwinmaulana35@yahoo.com
} 


\begin{abstract}
The increase in salt consumption is not proportional to the growth of salt production land. So far, the mapping of salt ponds has been carried out on a small to medium scale, so the accuracy is not too good. This study aimed to analyze changes in large-scale salt ponds in Rembang Regency during the period of 2005-2015. The data source used is a Very High-Resolution Satellite Image (CSRST) which has been corrected and other secondary data. Salt area was calculated through visual interpretation and manual detection. CSRST data usage by visual interpretation methods and manual detection had advantages in terms of geometric accuracy compared with the use of medium-sized image of automation methods. The analysis showed that the area of salt land in Rembang Regency increased during 20052015. The biggest increase occurred in 2005-2011, which increased by 546,255 ha or by 32\%. The increase in area during 2011-2015 was not significant by 198.45 ha (11.46\%). Area expansion was expected to occur in the next few years, but it was not expected to be significant because of the optimal land use in the most of Rembang already. Expansion of salt ponds remained possible by converting the existing rice fields on the coast of Rembang Regency. However, a comparative study of the economic value of rice fields and salt ponds must be carried out before converting the paddy fields to salt ponds.
\end{abstract}

Keywords: land use change; salt field area; salt pond; spatial approach

\title{
Pendahuluan
}

Lahan garam memiliki banyak manfaat bagi kehidupan manusia, yaitu sebagai salah satu suplai bahan makanan dan industri, siklus nutrisi, filter kontaminan, penyimpanan sedimen dan pengendalian banjir (Sun et al., 2018). Kebutuhan garam di Indonesia semakin meningkat dari tahun ke tahun. Berdasarkan data yang dirilis oleh Asosiasi Industri Pengguna Garam Indonesia (AIPGI) (2018), kebutuhan garam industri diperkirakan mencapai 3,7 juta ton (Gambar 1). Angka tersebut jauh di atas produksi garam nasional yang ada pada kisaran 916,9 ribu ton. Kekurangan jumlah pasokan garam menyebabkan pemerintah harus melakukan impor garam dari luar negeri (Berutu et al., 2014). Kebijakan impor banyak ditentang masyarakat, mengingat Indonesia merupakan negara maritim dengan garis pantai terpanjang ke-2 di dunia (Susanto et al., 2015).

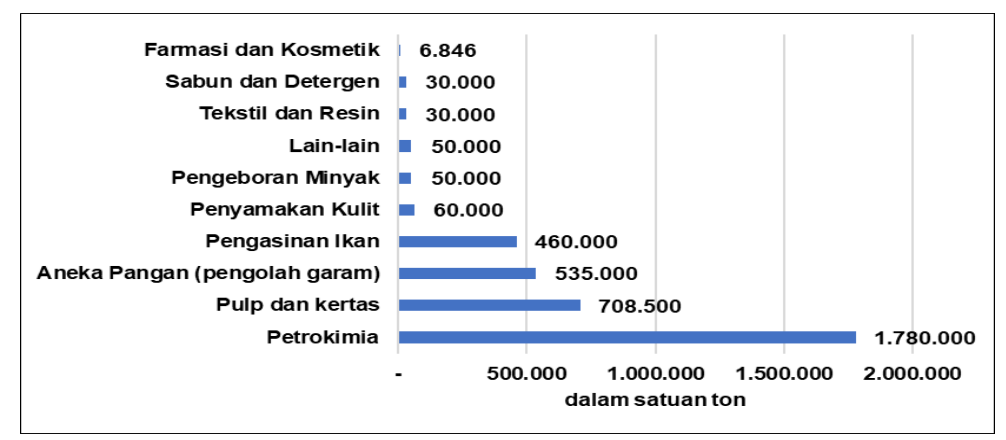

Sumber: Asosiasi Industri Pengguna Garam Indonesia (AIPGI), 2018

\section{Gambar 1. Kebutuhan Garam untuk Industri di Indonesia Tahun 2018}

Pengelolaan garam di Indonesia harus dilakukan secara baik sehingga segala potensi yang ada dapat dimanfaatkan secara maksimal. Salah satu upaya untuk perencanaan pengelolaan lahan garam adalah melakukan pemetaan kondisi eksisting dan potensi lahan garam. Berdasarkan analisis data spasial, masyarakat maupun pemerintah dapat mengidentifikasi (1) luas lahan garam eksisting; (2) luas lahan potensial; (3) teknik pengelolaan lahan garam; serta (4) manajemen risiko tambak garam dengan tepat. 
Salah satu daerah yang memiliki potensi garam yang cukup tinggi adalah Kabupaten Rembang di Jawa Tengah. Produksi garam di Kabupaten Rembang merupakan yang terbesar ke-2 di Provinsi Jawa Tengah setelah Kabupaten Pati (Jaya et al., 2016). Merujuk pada Saputro (2011), luas lahan garam di Kabupaten Rembang mencapai 1.731,22 ha. Lahan garam paling luas terdapat di Kecamatan Kaliori, sedangkan paling sempit di Kecamatan Sluke. Berdasarkan data yang dirilis Kementerian Kelautan dan Perikanan (2015), luas lahan garam di Kabupaten Rembang tahun 2015 adalah 1.568,65 ha dengan produksi sebesar 139,29 ton/musim.

Perhitungan luas lahan garam dapat dilakukan dengan empat metode yaitu pengukuran terestris, interpretasi data citra satelit/foto udara, otomatisasi dan kombinasi. Cara terbaik adalah dengan survei terestris, namun membutuhkan biaya besar dan waktu yang lama. Metode otomatisasi memiliki keunggulan dalam hal kecepatan analisis, namun pada beberapa kasus pemetaan skala besar, kualitas visual yang dihasilkan tidak terlalu baik. Cara yang paling mudah adalah interpretasi visual dan deteksi manual. Cara ini membutuhkan waktu yang lama, namun memiliki kenampakan visual paling baik dibandingkan metode lainnya, sehingga cocok digunakan untuk pemetaan skala besar.

Penelitian terkait pemetaan tambak garam telah dilakukan oleh beberapa peneliti terdahulu. Darvishzadeh et al. (2019) mengkaji perubahan vegetasi dan lahan garam secara temporal dengan menggunakan data Sentinel-2 Level 1C. Hasil analisis memiliki ketelitian menengah karena data yang digunakan memiliki resolusi 60 meter. Campbell and Wang (2020) menggunakan citra Landsat 7 dan Landsat 8 untuk monitoring lahan garam di kepesisiran pantai Atlantik. Ketelitian yang dihasilkan lebih baik karena resolusi Landsat yang digunakan lebih tinggi daripada Sentinel-2 Level 1C, namun masih belum cukup baik untuk digunakan sebagai dasar perencanaan pada level kota/kabupaten. Syam (2018) serta Wiyanto and Sulistiorini (2018) menggunakan citra Google Earth untuk pemetaan lahan garam. Citra Google Earth memiliki keunggulan dalam hal visual, namun memiliki kelemahan dalam ketelitian geometrik. Analisis lahan garam pada skala besar menarik untuk dikaji mengingat masih sedikit peneliti yang memanfaatkan data CSRST terortorektifikasi.

Kajian terkait perubahan lahan garam menarik untuk dikaji, terutama pada kelas pemetaan skala besar yang masih jarang dilakukan oleh peneliti terdahulu. Data CSRST terortorektifikasi dapat diolah sehingga menghasilkan peta lahan garam skala besar yang memiliki ketelitian geometrik yang lebih baik dan dapat dipertanggungjawabkan. Tujuan dari penelitian ini adalah untuk menganalisis perubahan luas lahan garam pada skala besar yang ada di Kabupaten Rembang selama periode 2005-2015 dengan menggunakan data CSRST terortorektifikasi.

\section{Metode Penelitian}

Penelitian ini dilakukan di Kabupaten Rembang, Jawa Tengah (Gambar 2). Secara administratif, Kabupaten Rembang berbatasan dengan Laut Jawa dan diapit oleh tiga kabupaten, yaitu Kabupaten Blora, Pati dan Tuban. Berdasarkan data yang dirilis oleh Badan Pusat Statistik (BPS) di tahun 2017, Kabupaten Rembang memiliki luas 101.408 ha (BPS Kabupaten Rembang, 2017). Kawasan pesisir Kabupaten Rembang didominasi oleh lahan garam, hutan, mangrove, permukiman dan lahan pertanian (Kusyuniadi, 2018; Maulana et al., 2016a; Purnomo et al., 2015; Roziqin, 2018). Mata pencaharian utama masyarakat di wilayah pesisir Kabupaten Rembang adalah petani, nelayan, peternak dan petani garam. Pertanian garam di Kabupaten Rembang terdapat di Kecamatan Kaliori, Rembang, Lasem dan Sluke (Andriyani et al., 2013). Kecamatan Kaliori merupakan pusat lahan garam di Kabupaten Rembang, sedangkan lahan garam paling sempit terdapat di Kecamatan Sluke. 


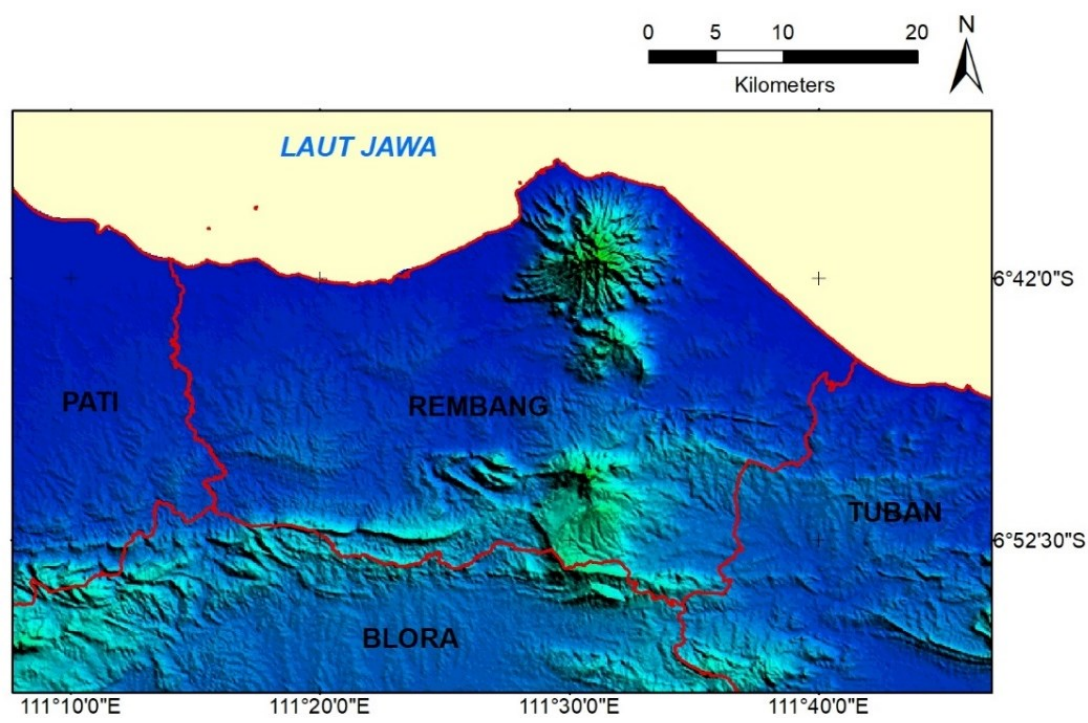

Gambar 2. Lokasi Penelitian

Kabupaten Rembang memiliki morfologi pesisir yang datar dengan panjang pantai berkisar 63,5 km, sehingga berpotensi untuk dimanfaatkan sabagai lahan garam (Kismartini \& Yusuf, 2015; Maulana et al., 2016b). Kabupaten Rembang terdiri dari setidaknya tiga formasi geologi, yaitu: (1) Endapan Aluvium (Qa); (2) Batuan Gunungapi Lasem (Qvl); dan (3) Formasi Mundu (Tmpm) (Kadar \& Sudijono, 1993). Penelitian yang dilakukan Wulan et al (2016) menunjukkan bahwa wilayah pesisir Kabupaten Rembang terdiri dari tiga bentukan asal proses, yaitu: (1) bentukan asal marin; (2) bentukan asal fluvial; dan (3) bentukan asal vulkanik. Bentukan asal marin dan fluvial membentang di sepanjang pesisir Kabupaten Rembang mulai dari Kecamatan Kaliori di sisi paling barat hingga Kecamatan Sarang di sisi paling timur. Bentuk lahan marin dan fluvial berpotensi untuk dimanfaatkan sebagai lahan garam.

Data dasar yang digunakan dalam penelitian ini adalah citra satelit resolusi sangat tinggi (CSRST) tahun 2015 yang bersumber dari Badan Informasi Geospasial (2015). Data CSRST diolah (ortorektifikasi) agar dapat digunakan sebagai dasar pemetaan yang sesuai dengan standar ketelitian yang telah ditetapkan oleh pemerintah. Proses ortorektifikasi diawali dengan melakukan rekonstruksi maupun menggabungkan potongan-potongan (tile) data citra (assembling tiles). Proses selanjutnya adalah proses penajaman citra (pansharpening) sehingga diperoleh resolusi $0.5 \mathrm{~m}$. Pricking dilakukan untuk memasukkan titik hasil Ground Control Point (GCP) ke dalam citra sehingga terkoreksi secara geometrik. Proses selanjutnya adalah mozaik dan dilakukan orto generate. Akurasi hasil ortorektifikasi CSRST dicek dengan menggunakan titik Independent Control Point (ICP) dengan jumlah titik minimal 12. Hasil akhir uji akurasi menunjukkan bahwa hasil ortorektifikasi masuk dalam ketelitian Kelas 3 sesuai dengan Peraturan Kepala Badan Informasi Geospasial Nomor 15 Tahun 2014 tentang Pedoman Teknis Ketelitian Peta Dasar (Badan Informasi Geospasial, 2014)

Metode yang digunakan untuk mengidentifikasi kenampakan lahan garam di Kabupaten Rembang adalah dengan interpretasi visual dan deteksi manual. Interpretasi foto udara dilakukan dengan menggunakan beberapa kunci intrepretasi foto udara yang meliputi rona atau warna, ukuran, bentuk, tekstur, pola dan asosiasi (Maulana et al., 2016c; Maulana \& Wulan, 2015). Data CSRST dengan resolusi sangat tinggi memungkinkan 
interpreter untuk melihat dengan jelas luas tambak dan batas ataupun pematang tambak. Berdasarkan interpretasi CSRST dapat dihasilkan persil-persil tambak garam dengan skala 1:5.000 (minus data hipsografi).

Data hasil luas lahan garam selanjutnya diintegrasikan dengan data produktivitas garam di Kabupaten Rembang yang dipublikasikan oleh KKP. Berdasarkan data KKP di tahun 2015, produktivitas lahan garam rata-rata di Kabupaten Rembang adalah 139,29 ton/ha/musim. Nilai tersebut masih relevan karena akuisisi data dasar yang digunakan untuk penelitian ini adalah tahun 2015 .

\section{Hasil dan Pembahasan}

Perubahan penggunaan lahan merupakan fenomena alam yang tidak dapat dihindari. Perubahan penggunaan lahan dapat diakibatkan oleh dua faktor utama, yaitu faktor alam dan antropogenik. Faktor alam yang menyebabkan perubahan luas kawasan pesisir adalah abrasi dan sedimentasi (Maulana et al. 2016a; Wulan et al. 2016). Dewasa ini, perubahan penggunaan lahan di kawasan pesisir berlangsung dengan cepat terkait perubahan iklim dan pertumbuhan ekonomi secara global. Kabupaten Rembang sebagai salah satu Kabupaten di Indonesia yang memiliki kawasan pesisir juga mengalami perubahan penggunaan lahan.

Luas lahan garam di pesisir Kabupaten Rembang terus berubah dari waktu ke waktu. Secara umum, keberadaan lahan garam di pesisir pantai dipengaruhi oleh beberapa hal seperti topografi lokal, salinitas air laut, jenis tanah, banjir, tingkat sedimentasi, insolasi, kecepatan angin, kelembapan, ekosistem lingkungan, dan aktivitas manusia (Isacch et al., 2006; Silvestri et al., 2005). Kabupaten Rembang tersusun atas dua bentuk lahan utama, yaitu fluvial dan marin sehingga dinamika perubahan penggunaan lahan garam di pesisir Kabupaten Rembang berlangsung dengan cepat. Salah satu faktor yang memengaruhinya adalah terjadinya gelombang tinggi (Arini et al., 2014; Hanan et al., 2015).

Berdasarkan Pemerintah Daerah Kabupaten Rembang (2010), luas lahan garam di Kabupaten Rembang pada tahun 2005 adalah 1.184,965 ha. Luas lahan paling besar terdapat di Kecamatan Kaliori dengan luas 536,84 ha, sedangkan lahan garam paling sempit di Kecamatan Sluke dengan luas 21,42 ha. Kecamatan Kaliori sudah menjadi lumbung garam Kabupaten Rembang sejak lama. Kecamatan Kaliori memiliki lereng datar dengan tingkat kemiringan lereng $0-2 \%$ sehingga memudahkan untuk melakukan pengolahan garam. Kecamatan Kaliori juga tidak memiliki barier, sehingga sirkulasi angin berlangsung dengan baik. Insolasi yang yang baik juga menjadi faktor penting sehingga pertanian garam di Kecamatan Kaliori tumbuh dengan pesat.

Hasil penelitian yang dilakukan oleh Saputro (2011) menunjukkan bahwa luas lahan garam di Kabupaten Rembang adalah 1.731,22 ha. Perubahan luas lahan garam secara signifikan dalam kurun waktu 2005 hingga 2011. Setiyarso et al. (2016) juga mengemukakan bahwa terjadi perubahan signifikan dari sawah menjadi lahan garam di pesisir Kabupaten Rembang. Salah satu latar belakang konversi lahan tersebut adalah sawah memiliki kerentanan yang tinggi terhadap gelombang pasang di pesisir utara Jawa. Petani tambak memiliki kerentanan lebih rendah daripada petani sawah saat terjadi gelombang karena masih bisa bertahan saat terjadi gelombang tinggi dengan mengubah lahan garamnya menjadi budidaya perikanan seperti udang.

Penambahan luas lahan garam pada periode 2005 hingga 2011 mencapai 546,255 ha atau sebesar $32 \%$. Penambahan luas lahan garam paling signifikan terjadi di Kecamatan Kaliori. Luas lahan garam di Kecamatan Kaliori di tahun 2005 adalah 536,84 ha dan pada tahun 2011 luas lahan garam di Kecamatan Kaliori mencapai 1.006,49 ha. Penambahan luas lahan garam di Kecamatan Kaliori mencapai 481,98 ha. Perluasan lahan garam di Kecamatan Rembang, Lasem, Sarang dan Sluke juga terjadi, namun nilainya tidak 
signifikan. Perubahan luas garam di empat kecamatan tersebut paling besar terdapat di Kecamatan Lasem dengan luas perubahan lahan berada pada kisaran 38,42 ha atau sekitar $2,22 \%$. Salah satu faktor yang membuat pertumbuhan luas lahan garam di Kabupaten Rembang, khususnya di Kecamatan Kaliori terjadi dengan cepat adalah karena akses jalan dari dan menuju lahan garam cukup baik. Hal tersebut memudahkan petani garam untuk memasarkan hasil produksi garam. Aksesibilitas yang baik juga membuat ongkos produksi dapat ditekan sehingga keuntungan yang didapat lebih besar.

Interpretasi visual dan deteksi manual dilakukan untuk memperbaharui data luas lahan garam di Kabupaten Rembang. Data yang digunakan merupakan CSRST tahun 2015. Perekaman data CSRST dilakukan di musim kemarau sehingga proses pengolahan garam terlihat jelas pada citra. Kenampakan yang paling jelas pada lahan garam di Kabupaten Rembang dapat diamati dari sisi pola, rona, bentuk, tekstur dan asosiasi (Gambar 3).

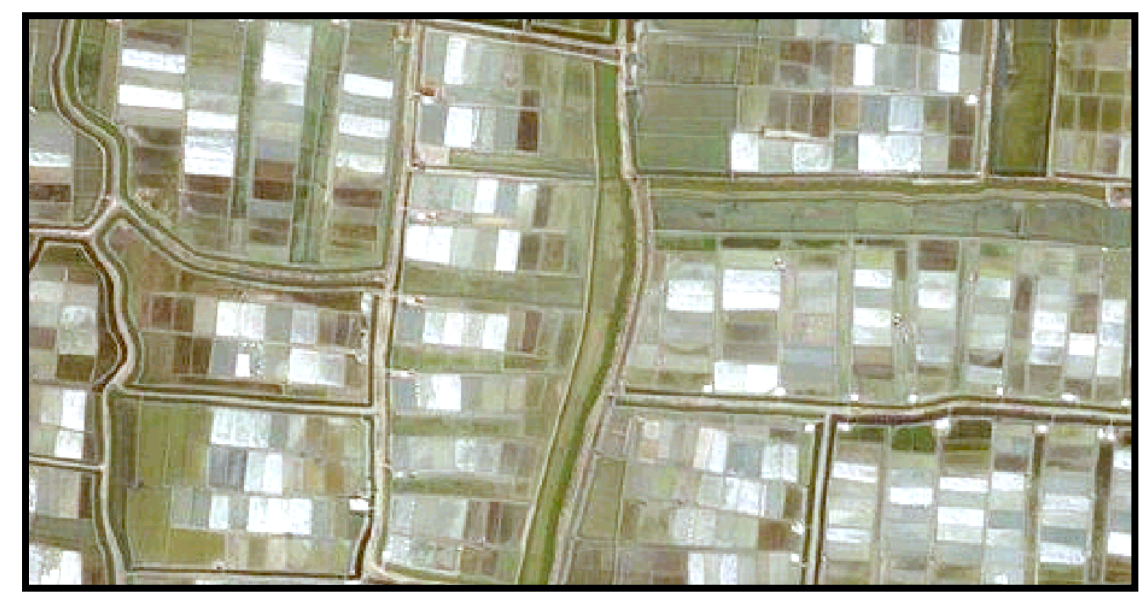

\section{Gambar 3. Kenampakan Lahan Garam di Kabupaten Rembang}

Rona lahan garam terlihat putih cerah karena pengolahan garam sedang berlangsung. Lahan garam biasanya berbentuk kubistik (persegi ataupun persegi panjang) dan beberapa terdapat bentuk trapesium yang menyesuaikan dengan aliran sungai di sekitar lahan garam. Beberapa lahan garam berasosiasi dengan sawah dengan bentuk yang sama (kubistik), namun dapat dibedakan dengan mudah mengingat rona lahan garam berwarna putih cerah, sedangkan lahan persawahan biasanya berwarna hijau cerah. Pola lahan garam juga cukup mudah diamati dari citra karena memiliki pola yang jelas, yaitu memiliki bentuk dan rona yang sama dan memiliki banyak perulangan. Asosiasi lahan garam biasanya berdampingan dengan kolam peminihan dengan rona hijau tua maupun hijau pucat. Tekstur lahan garam cenderung lebih kasar dibanding tambak udang dan tambak ikan.

Hasil interpretasi menunjukkan luas lahan garam di Kabupaten Rembang di tahun 2015 adalah 1.929,67 ha (Gambar 4). Kecamatan Kaliori merupakan wilayah dengan lahan garam paling luas, yaitu 1.102,53 ha, disusul oleh Kecamatan Lasem dengan luas lahan garam berkisar 449,97 ha. Kecamatan dengan luas lahan garam paling sempit terdapat di Kecamatan Sluke dengan luas 26,91 ha. Terdapat beberapa program pemerintah yang mendukung Kecamatan Kaliori untuk bertahan selama beberapa periode sebagai daerah dengan luas dan produktivitas garam tertinggi di Kabupaten Rembang. Penelitian yang dilakukan Amanda and Buchori (2015) menunjukkan bahwa tingkat keberdayaan masyarakat penerima bantuan pemerintah terhadap petani garam cukup tinggi. Hal tersebut dibuktikan dengan tingginya tingkat partisipasi, kemampuan, kemandirian, dan keberlanjutan pertanian garam. 


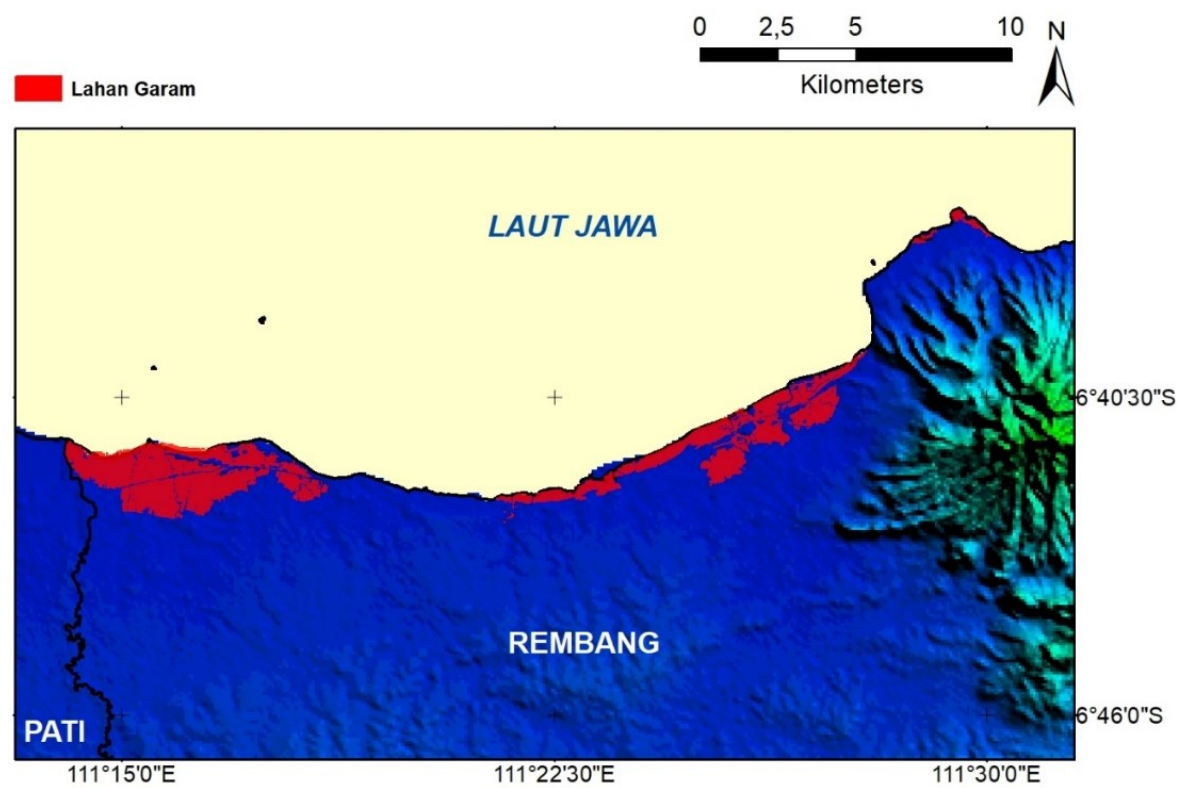

\section{Gambar 4. Sebaran Lahan Garam di Kabupaten Rembang}

Konsistensi kenaikan luas lahan garam terjadi merata di Kaliori, Sluke, Lasem, Rembang dan Sarang. Hal tersebut menunjukkan bahwa bidang pertanian garam masih diminati masyarakat pesisir Rembang. Terjadi kenaikan luas lahan garam sebesar 198,45 ha $(11,46 \%)$ dibanding tahun 2011. Nilai perkembangan luas lahan garam dalam empat tahun tersebut tidak terlalu signifikan dibandingkan periode 2005-2011. Terdapat 44 titik lahan garam baru yang tersebar di seluruh wilayah Kabupaten Rembang. Penambahan lahan garam paling besar terjadi di Kecamatan Kaliori dengan penambahan sebesar 96,04 ha, disusul dengan Kecamatan Rembang dengan luas 52,27 ha. Wilayah yang cenderung stagnan adalah lahan garam di Kecamatan Sarang, dengan penambahan luas lahan garam sebesar 0,60 ha. Secara keseluruhan luas lahan garam di tiga periode terakhir dapat dilihat pada Tabel 1.

Tabel 1. Luas Perubahan Penggunaan Lahan Garam dari Tahun 2005-2015

\begin{tabular}{clrrr}
\hline \multirow{2}{*}{ No. } & \multirow{2}{*}{ Kecamatan } & \multicolumn{3}{c}{ Luas (Ha) } \\
\cline { 3 - 5 } & & $\mathbf{2 0 0 5}$ & $\mathbf{2 0 1 1}$ & $\mathbf{2 0 1 5}$ \\
\hline 1 & Kaliori & 524,51 & $1.006,49$ & $1.102,53$ \\
2 & Rembang & 246,37 & 264,75 & 317,02 \\
3 & Lasem & 364,35 & 402,77 & 449,97 \\
4 & Sarang & 28,32 & 32,64 & 33,24 \\
5 & Sluke & 21,42 & 24,57 & 26,91 \\
\hline
\end{tabular}

Tren perubahan penggunaan lahan di pesisir Kabupaten Rembang menunjukkan bahwa luasan lahan garam terus bertambah dalam beberapa tahun terakhir (Gambar 5). Penambahan lebih besar terjadi dalam kurun 2005 hingga 2011, sedangkan pada periode 2011 hingga 2015 terjadi penambahan namun nilainya tidak terlalu signifikan dikarenakan berkurangnya stok lahan potensial untuk tambak garam. Berdasarkan hasil interpretasi, sebenarnya terdapat beberapa bekas lahan garam di 2011 yang berubah fungsi menjadi sawah, permukiman, jalan, maupun saluran irigasi. Perubahan tersebut diakibatkan oleh 
beberapa faktor antropogenik, khususnya kebutuhan masyarakat sekitar tambak garam terhadap lahan untuk permukiman.

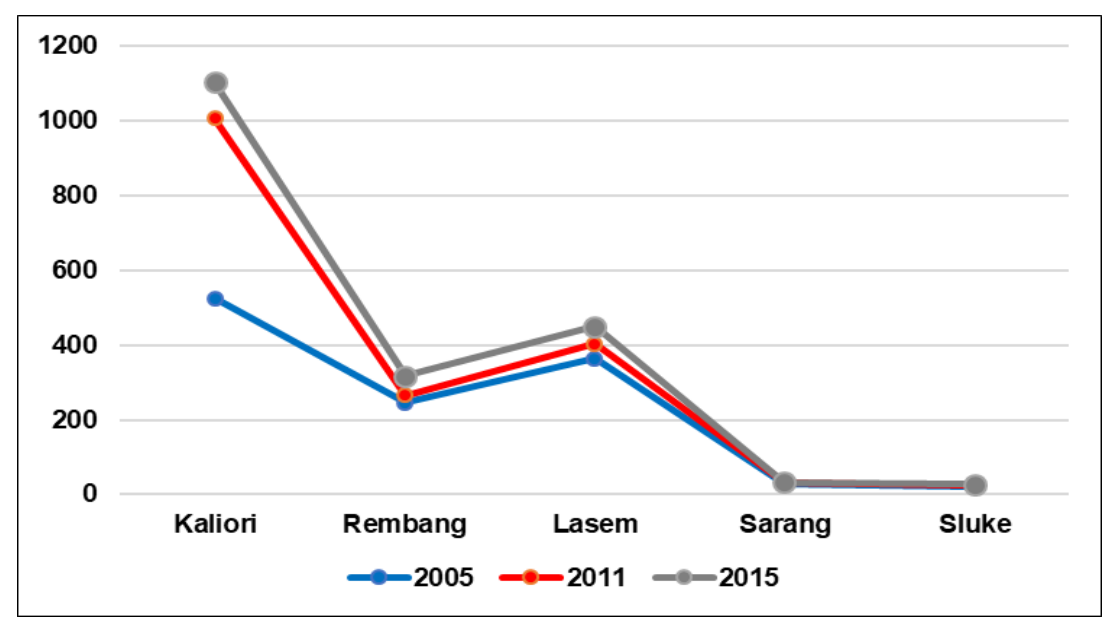

\section{Gambar 5. Tren Perubahan Luas Lahan Garam di Kabupaten Rembang}

Perubahan penggunaan lahan di pesisir Kabupaten Rembang sangat wajar terjadi mengingat dinamika di kawasan pesisir yang cukup rumit. Terdapat proses abrasi-akresi serta sedimentasi di pesisir Kabupaten Rembang (Maulana et al. 2016a). Beberapa lahan garam yang ada di 2011 hilang di tahun 2015 akibat abrasi dan terdapat penambahan lahan garam baru di tempat lain akibat proses akresi. Berdasarkan pengamatan visual pada CSRST penambahan lahan garam masih mungkin terjadi karena terdapat beberapa wilayah yang potensial untuk dijadikan lahan garam, namun nilainya tidak akan sebesar periode 2005-2011. Hal tersebut dipengaruhi oleh lahan terbuka di pesisir Kabupaten Rembang sudah mulai habis dan telah dimanfaatkan secara optimal oleh masyarakat. Penambahan lahan garam ke arah selatan sebenarnya masih mungkin dilakukan, namun harus mengonversi sawah masyarakat. Perlu kajian mendalam sebelum konversi lahan sawah ke lahan garam, untuk menentukan nilai ekonomi potensial dan dampak terhadap lingkungan. Konversi lahan garam menjadi permukiman juga masih memungkinkan dilakukan di Kecamatan Rembang karena berdasarkan Rencana Tata Ruang Wilayah (RTRW) Kabupaten Rembang, lahan garam di Kecamatan Rembang seharusnya difungsikan untuk permukiman (Izza et al., 2020).

\section{Kesimpulan}

Citra satelit dapat dimanfaatkan untuk mengidentifikasi sebaran lahan garam dari waktu ke waktu. Hasil kajian ini menunjukkan pertambahan luas lahan garam di Kabupaten Rembang dari 2005 hingga 2015. Pertambahan luas lahan terjadi konstan meskipun grafiknya cenderung melambat. Pertumbuhan lahan garam di setiap tahun menunjukkan bahwa eksistensi industri garam masih menjadi salah satu primadona masyarakat pesisir Rembang. Di sisi lain, gempuran impor garam turut mengancam eksistensi petani garam, khususnya di Kabupaten Rembang. Hal ini disebabkan skala produksinya masih rumahan dan peralatannya juga masih belum mumpuni untuk dikembangkan menjadi industri besar.

Penelitian ini berimplikasi pada optimalisasi pemanfaatan lahan garam dan perencanaan wilayah pesisir yang lebih terperinci. Pengembangan kawasan lahan garam yang telah dikaji dapat memberikan gambaran tentang bagaimana perubahan bentuk dan luasan lahan garam di pesisir Kabupaten Rembang pada masa mendatang. Integrasi data 
spasial dan data statistik dapat dilakukan dengan menggunakan data spasial berskala besar sehingga tidak hanya diketahui luasan area lahan garam, namun juga letaknya secara astronomis. Penelitian lanjutan yang dapat dilakukan adalah melakukan pengukuran terestris lahan garam di Kabupaten Rembang sehingga dapat diperoleh nilai presisi yang lebih tinggi. Pembaharuan data luas lahan garam di seluruh Indonesia harus dilakukan untuk kepentingan prediksi produksi garam nasional dan kepentingan perpajakan.

\section{Ucapan Terima Kasih}

Peneliti banyak mengucapkan terima kasih kepada Badan Informasi Geospasial yang memfasilitasi peneliti dalam melakukan penelitian ini. Tidak lupa peneliti memberikan apresiasi yang paling tinggi kepada atasan peneliti di Badan Informasi Geospasial yang telah memberikan keleluasaan peneliti untuk kembali menulis. Ucapan terima kasih juga dihaturkan kepada Prof. Dr.rer.nat Junun Sartohadi, M.Sc yang selalu menginspirasi penulis untuk berkarya.

\section{Daftar Pustaka}

Amanda, R. P., \& Buchori, I. (2015). Efektivitas program pemberdayaan usaha garam rakyat (PUGAR) tahun 2014 terhadap tingkat keberdayaan petani garam rakyat di Kecamatan di Kecamatan Kaliori. Jurnal Teknik PWK, 4(4), 554-563.

Andriyani, R. P., Suadi, S., \& Djasmani, S. S. (2013). Analisis usaha tambak garam di Desa Gedongmulyo Kecamatan Lasem Kabupaten Rembang. Jurnal Perikanan, 15(2), 68-77. doi:10.22146/jfs.9104.

Arini, D. P., Indarjo, A., \& Helmi, M. (2014). Kajian kerentanan pantai di Pesisir Kabupaten Rembang Provinsi Jawa Tengah. Journal of Marine Research, 3(4), 462-468.

Asosiasi Industri Pengguna Garam Indonesia (AIPGI). (2018). Berapa kebutuhan garam industri? Retrieved from https://databoks.katadata.co.id/datapublish/2018/02/23/berapa-kebutuhan-garam-industri\#.

Badan Informasi Geospasial. (2014). Peraturan Kepala Badan Informasi Geospasial Nomor 15 Tahun 2014 Tentang Pedoman Teknis Ketelitian Peta Dasar. Bogor: Badan Informasi Geospasial.

Badan Informasi Geospasial. (2015). Citra satelit resolusi sangat tinggi (CSRST). Bogor: Badan Informasi Geospasial.

Berutu, B., Alfonso, D., \& Susilowati, I. (2014). Analisis efisiensi penggunaan faktor-faktor produksi garam di Kecamatan Kaliori Kabupaten Rembang. Universitas Diponegoro.

BPS Kabupaten Rembang. (2017). Kabupaten Rembang dalam angka tahun 2017. Rembang: BPS Kabupaten Rembang.

Campbell, A. D., \& Wang, Y. (2020). Salt marsh monitoring along the mid-Atlantic coast by Google Earth Engine enabled time series. PLoS One, 15(2), 1-23. doi:10.1371/journal.pone.0229605.

Darvishzadeh, R., Wang, T., Skidmore, A., Vrieling, A., O’Connor, B., Gara, T. W., Ens, B. J., \& Paganini, M. (2019). Analysis of sentinel-2 and rapideye for retrieval of leaf area index in a saltmarsh using a radiative transfer model. Remote Sensing, 11(6), 1-22. doi:10.3390/rs11060671.

Hanan, A., DS, A. A., \& Helmi, M. (2015). Analisis dampak gelombang tinggi pada musim barat terhadap penggunaan lahan pesisir di Kabupaten Rembang, Provinsi Jawa Tengah. Jurnal Oseanografi, 4(1), 100108.

Isacch, J. P., Costa, C. S. B., Rodríguez-Gallego, L., Conde, D., Escapa, M., Gagliardini, D. A., \& Iribarne, O. O. (2006). Distribution of saltmarsh plant communities associated with environmental factors along a latitudinal gradient on the south-west Atlantic coast. Journal of Biogeography, 33(5), 888-900. doi:10.1111/j.1365-2699.2006.01461.x.

Izza, A. S., Pribadi, C. B., \& Budisusanto, Y. (2020). Analisis kesesuaian kawasan terbangun dengan rencana tata ruang wilayah di Kawasan Sempadan Pantai Kabupaten Rembang. Geoid: Journal of Geodesy and Geomatics, 16(1), 1-7. doi:10.12962/j24423998.v16i1.7972.

Jaya, N. T. S. P., Hartati, R., \& Widianingsih, W. (2016). Produksi garam dan bittern di tambak garam. Jurnal Kelautan Tropis, 19(1), 43-47. doi:10.14710/jkt.v19i1.599. 
Kadar, D., \& Sudijono, S. (1993). Peta geologi bersistem Indonesia lembar: Rembang 1509-1 \& 4 skala 1:100.000. Bandung: Pusat Penelitian dan Pengembangan Geologi.

Kementerian Kelautan dan Perikanan. (2015). Produksi garam Indonesia. Jakarta: Kementerian Kelautan dan Perikanan.

Kismartini, K., \& Yusuf, M. (2015). Stakeholders analysis: Managing coastal policy implementation in Rembang District. Procedia Environmental Sciences, 23(338-345). doi:10.1016/j.proenv.2015.01.049.

Kusyuniadi, I. (2018). Policy implementation study on spatial planning for environmental conflict (study location: Rembang Regency). In E3S Web Conference, Volume 31, 2018. The 2nd International Conference on Energy, Environmental and Information System (ICENIS 2017) (pp. 1-8). doi:10.1051/e3sconf/20183109015.

Maulana, E, \& Wulan, T. R. (2015). Identifikasi agihan barkhan pada zona inti gumuk pasir Parangtritis dengan menggunakan data UAV. In Simposium Nasional Sains Geoinformasi IV 2015: Penguatan Peran Sains Informasi Geografi dalam Mendukung Penanganan Isyu-Isyu Strategis Nasional (pp. 307-313). Yogyakarta: PUSPICS, Fakultas Geografi, Universitas Gadjah Mada.

Maulana, E, Wulan, T. R., Wahyuningsih, D. S., Mahendra, W. W. Y., \& Siswanti, E. (2016a). Strategi pengurangan risiko abrasi di Pesisir Kabupaten Rembang, Jawa Tengah. In Prosiding Seminar Nasional Geografi UMS 2016 (pp. 389-398).

Maulana, E, Wulan, T. R., Siswanti, E., Wahyuningsih, D. S., Rahmadana, A. D. W., \& Putra, M. D. (2016b). Analysis of land capability in alluvial plain and volcanic slope of Rembang District using landforms approach. In ICOIRS 2016: The 2nd International Conference of Indonesian Society for Remote Sensing Remote Sensing for a Better Governance (pp. 252-259). Yogyakarta: PUSPICS, Faculty of Geography, Universitas Gadjah Mada.

Maulana, E, Wulan, T. R., Putra, M. D., Maulia, N., Ibrahim, F., Wahyuningsih, D. S., \& Putra, A. S. (2016c). Damage and lost assessment (DALA) after giant tidal wave using UAV data in Depok Beach, Parangtritis, Kretek, Bantul, Yogyakarta (case study: giant tidal wave period june 2016). In ICOIRS 2016: The 2nd International Conference of Indonesian Society for Remote Sensing: Remote Sensing for a Better Governance (pp. 175-181). Yogyakarta: PUSPICS, Faculty of Geography, Universitas Gadjah Mada.

Pemerintah Daerah Kabupaten Rembang. (2010). Peraturan Daerah Nomor 1 Tahun 2010 tentang Rencana Pembangunan Jangka Panjang Daerah Kabupaten Rembang Tahun 2005-2025. Rembang: Pemerintah Daerah Kabupaten Rembang.

Purnomo, M. B., Hizbaron, D. R., \& Damen, M. (2015). Community-based analysis on mangrove forest changes in Rembang District, Central Java Province, Indonesia. Jurnal Kependudukan Indonesia, 10(1), 1-10. doi:10.14203/jki.v10i1.51.

Roziqin, A. (2018). Environmental policy of mangroves management in Rembang Regency. In E3S Web Conference Volume 31, 2018 The 2nd International Conference on Energy, Environmental and Information System (ICENIS 2017) (pp. 1-6). doi:10.1051/e3sconf/20183109002.

Saputro, G. B. (2011). Informasi geospasial lahan garam Indonesia. Bogor: Badan Koordinasi Survei dan Pemetaan Nasional (Bakosurtanal).

Setiyarso, B., Muryani, C., \& Sarwono, S. (2016). Analisis perubahan garis pantai dan perubahan penggunaan lahan Kabupaten Rembang tahun 2003-2014. Jurnal GeoEco, 2(1), 67-79.

Silvestri, S., Defina, A., \& Marani, M. (2005). Tidal regime, salinity and salt marsh plant zonation. Estuarine, Coastal and Shelf Science, 62(1-2), 119-130. doi:10.1016/j.ecss.2004.08.010.

Sun, C., Fagherazzi, S., \& Liu, Y. (2018). Classification mapping of salt marsh vegetation by flexible monthly NDVI time-series using Landsat imagery. Estuarine, Coastal and Shelf Science, 213, 61-80. doi:10.1016/j.ecss.2018.08.007.

Susanto, H., Rokhati, N., \& Santosa, G. W. (2015). Development of traditional salt production process for improving product quantity and quality in Jepara District, Central Java, Indonesia. Procedia Environmental Sciences, 23, 175-178. doi:10.1016/j.proenv.2015.01.027.

Syam, M. (2018). Pemanfaatan citra satelit Landsat 8 untuk inventarisasi lahan tambak garam Kabupaten Jeneponto. Jurnal Sains Dan Pendidikan Fisika, 14(2), 89-96. doi:10.35580/jspf.v14i2.10821.

Wiyanto, D. B., \& Sulistiorini, D. A. (2018). Aplikasi sistem informasi geografis untuk pemetaan tambak garam di Kabupaten Sidoarjo. Jurnal Rekayasa, 11(1), 1-10. doi:10.21107/rekayasa.v11i1.4119.

Wulan, T. R., Ambarwulan, W., Siswanti, E., Maulana, E., Mahendra, I. W. W. Y., \& Wahyuningsih, D. S. (2016). Variasi kondisi airtanah sebagian pesisir Kabupaten Rembang kaitannya dengan bentuklahan. In Prosiding Seminar Nasional Kelautan 2016, Universitas Trunojoyo Madura, 27 Juli 2016 (pp. 173-179). 